\title{
A case of Wolfram syndrome with chronic renal failure
}

\section{Hüseyin Anıl Korkmaz, MD}

Division of Pediatric Endocrinology, Balıkesir Atatürk State Hospital, Balıkesir, Turkey
Received: 20 June, 2018

Revised: 2 July, 2018

Accepted: 3 July, 2018

Address for correspondence:

Hüseyin Anıl Korkmaz, MD

Balıkesir Atatürk State Hospital, Division of Pediatric Endocrinology, Gaziosmanpaşa Mah. 381. Sok. İzmir Yol Mevkii No: 2 Altıeylül/Balıkesir, Turkey

Tel: +90-266-460-4000

Fax: +90-266-221-3516

E-mail: hanilkorkmaz@gmail.com https://orcid.org/0000-0001-58009014
Wolfram syndrome, rare neurodegenerative disorder, is known to be DIDMOAD (diabetes insipidus, diabetes mellitus, optic atrophy and deafness). ${ }^{1,2)}$ Majority of patients with Wolfram syndrome have mutations of the WFS1 (wolframin) on chromosome $4 .{ }^{1,2}$ Wolfram syndrome is also characterized with gastrointestinal autonomic neuropathy, cardiovascular disorders, hypergonadotrophic hypogonadism in males, neurologic and psychiatric disorders, urinary bladder dysfunction, and diabetic microvascular disorders. ${ }^{1,2)}$ There are rare case reports of Wolfram syndrome with chronic renal failure in the literature.

A 19-year-old male patient was admitted to our pediatric Emergency Department because of headache, chest pain and diurnal and nocturnal enuresis. He had been diagnosed with diabetes mellitus at 13 years of age (plasma glucose was $386 \mathrm{mg} / \mathrm{dL}$, urinary ketone negative, normal blood gases, serum C-peptide level $0.1 \mathrm{pmol} / \mathrm{mL}$ [0.15-1.10] and glycosylated hemoglobin value of as $9.6 \%)$ and had received four doses of regular insulin $(0.9 \mathrm{U} / \mathrm{kg} /$ day $)$ treatment. Antiinsulin antibody was $3 \mathrm{U}(0-8 \mathrm{U})$, anti-GAD $0.4 \mathrm{U} / \mathrm{mL}(<1 \mathrm{U} / \mathrm{mL})$, and islet cell antibody was negative at the diagnosis. He was the sixth child of apparently healthy consanguineous parents, born at full-term by normal vaginal delivery. Family history disclosed that his uncle, aunt and sister had diabetes mellitus. On physical examination; weight, $31 \mathrm{~kg}$ ( $<3 \mathrm{rd}$ percentile); height, $136.5 \mathrm{~cm}$ (<3rd percentile); blood pressure, 160/80 $\mathrm{mmHg}$; and pulse rate, 96 beats $/ \mathrm{min}$. He had bilateral blindness. High renal function tests (blood urea nitrogen, $78 \mathrm{mg} / \mathrm{dL}$; creatinine, $4.7 \mathrm{mg} / \mathrm{dL}$ ), serum electrolytes ( $\mathrm{Na}, 133.7 \mathrm{mmol} / \mathrm{L} ; \mathrm{K}, 4.2 \mathrm{mmol} / \mathrm{L} ; \mathrm{Cl}, 103.7 \mathrm{mmol} / \mathrm{L}$; serum calcium, $8.4 \mathrm{mg} / \mathrm{dL}$; serum phosphorus, $8 \mathrm{mg} / \mathrm{dL}$ ) and high parathyroid hormone $(321.63$ $\mathrm{pg} / \mathrm{mL}$; range, $15-65 \mathrm{pg} / \mathrm{mL}$ ) suggested chronic renal failure. Urinary ultrasound imaging disclosed small kidney size. Glomerular filtration rate was calculated as $13 \mathrm{~mL} / \mathrm{min} / 1.73 \mathrm{~m}^{2}$. Audiometric examination for Wolfram syndrome revealed bilateral sensorineural hearing loss. In addition, fundus oculi examination had demonstrated bilateral optic atrophy and no sign of diabetic retinopathy. A known homozygous mutation (Y508fsX541, c.1523_1524delAT) in exon 8 of WFS1 was found in the proband.

We report a case with wolfram syndrome accompanied by chronic renal failure. In a report from China, rapid development of severe renal and retinal complications were noted in some of the members of the family with Wolfram syndrome. ${ }^{3)}$ One case study reported a Wolfram syndrome patient with kidney transplantation due to dysplastic kidneys. ${ }^{4)}$ Hasan et al. ${ }^{5)}$ reported that a case with Wolfram syndrome developed end-stage renal failure and needed hemodialysis at the age of 14 years. Diabetes mellitus is generally the first clinical manifestation in Wolfram syndrome and develops during the first decade of life, at about 6 years of age in average. Since diabetes mellitus was not present with optic atrophy and bilateral sensorineural hearing loss at 13 years of age, diagnosis of Wolfram syndrome could not be made in our patient in childhood. It is important for diagnostic approach of children with autoantibodynegative diabetes and incomplete features of Wolfram syndrome. Wolfram syndrome should be considered when the diabetes patients present with hearing loss, diabetes insipidus or optic atrophy.

\section{Conflict of interest}

No potential conflict of interest relevant to this article was reported. 


\section{Acknowledgments}

This manuscript was presented in the 19th European Congress of Endocrinology as poster and was presented in National Endocrine Congress.

\section{References}

1 Barrett TG, Bundey SE, Macleod AF. Neurodegeneration and diabetes: UK nationwide study of Wolfram (DIDMOAD) syndrome. Lancet 1995;346:1458-63.
2. Korkmaz HA, Demir K, Hazan F, Ylldız M, Elmas ÖN, Özkan B. Association of Wolfram syndrome with Fallot tetralogy in a girl. Arch Argent Pediatr 2016;114:e163-6.

3. Lim MC, Thai AC. A Chinese family with Wolfram syndrome presenting with rapidly progressing diabetic retinopathy and renal failure. Ann Acad Med Singapore 1990;19:548-55

4. Ben-Dov IZ, Meiner V, Eid A. Kidney transplantation unraveling Wolfram syndrome: a case report. Transplantation 2001;72:958-60.

5. Hasan MA, Hazza I, Najada A. Wolfram's (DIDMOAD) syndrome and chronic renal failure. Saudi J Kidney Dis Transpl 2000;11:53-8. 